\title{
INTERPRETASI ‘KURANG LENGKAP’ BERKAS PENYELIDIKAN DALAM PERKARA DUGAAN PELANGGARAN HAK ASASI MANUSIA BERAT
}

\author{
Kajian Putusan Mahkamah Konstitusi Nomor 75/PUU-XIII/2015 \\ INTERPRETATION OF 'FILES INCOMPLETE' IN \\ THE INVESTIGATION CASE OF ALLEGATION \\ OF SEVERE INFRINGEMENTS OF HUMAN RIGHTS
}

An Analysis of Constitutional Court Decision Number 75/PUU-XIII/2015

\author{
Hwian Christianto \\ Fakultas Hukum Universitas Surabaya \\ Jl. Raya Kalirungkut Surabaya 60293 \\ E-mail: hw_christianto@ubaya.ac.id
}

Naskah diterima: 16 Februari 2017; revisi: 7 Mei 2018; disetujui 30 Juli 2018

http://dx.doi.org/10.29123/jy.v11i2.71

\begin{abstract}
ABSTRAK
Putusan Nomor 75/PUU-XIII/2015 atas permohonan pengujian Pasal 20 ayat (3) Undang-Undang Pengadilan Hak Asasi Manusia, memiliki aspek menarik terkait kepastian hukum dan keadilan. Pemohon menilai keberadaan istilah 'berkas kurang lengkap' dalam ketentuan a quo memberikan ketidakadilan karena tidak memberikan kepastian hukum. Sebaliknya, penyidik, dalam hal ini Jaksa Agung justu menganggap keberadaan rumusan tersebut memberikan kepastian hukum sekaligus keadilan yang dibutuhkan oleh pencari keadilan maupun masyarakat. Penelitian menggunakan metode penelitian studi kasus yang mendasarkan dokumen Putusan Mahkamah Konstitusi sebagai bahan hukum primer, dibandingkan dengan bahan hukum sekunder berupa teori hukum pidana dan hak asasi manusia. Hasil penelitian menunjukkan bahwa Putusan Nomor 75/PUU-XIII/2015 memberikan pertimbangan, bahwa pengaturan tersebut tetap konstitusional. Perbedaan pemahaman ini menunjukkan bahwa keberadaan berkas penyelidikan yang 'kurang lengkap'
\end{abstract}

dapat dimungkinkan. Hal tersebut dianggap sebagai kondisi praktis penegakan hukum yang menekankan kehati-hatian dan persamaan di hadapan hukum.

Kata kunci: berkas perkara, asas hukum acara pidana, constitutional rights, putusan hakim.

\section{ABSTRACT}

Constitutional Court Decision Number 75/PUUXIII/2015 on the request for a judicial review of Article 20 paragraph (3) of Law on Human Rights Court has an interesting aspect related to the rule of law and justice. The Petitioner considered that the term incomplete file' in the quo provision raises a sense of injustice because it cannot bring legal certainty. Instead, the investigator, in this case the Attorney General considers the formulation can actually provide legal certainty as well as sense of justice needed by the justice seekers and the community. This analysis uses case study research method based on the document of Constitutional Court Decision as the primary law material compared with 
secondary law material in the form of criminal law theory and human rights. The results of the analysis show that the Constitutional Court Decision Number 75/PUU-XIII/2015 considers that the arrangement is still constitutional. This distinction of understanding suggests that 'case file incomplete' may be possible. It is regarded as the practical conditions of law enforcement that emphasize prudence and equality before the law.

Keywords: case file, principles of criminal procedure law, constitutional rights, judge's decision.

\section{PENDAHULUAN}

\section{A. Latar Belakang}

Pengajuan permohonan uji materiil atas Pasal 20 ayat (3) Undang-Undang Pengadilan Hak Asasi Manusia memiliki daya tersendiri baik dari sisi substansi perkara maupun bentuk perkara yang dimohonkan. Pemohon menilai adanya penilaian yang berbeda antara Komnas HAM dan Jaksa Agung terkait rumusan Pasal 20 ayat (3) Undang-Undang Pengadilan Hak Asasi Manusia, yang mencantumkan secara khusus istilah "tidak lengkap" atas berkas perkara penyelidikan. Apa yang dinilai oleh penyelidik (dalam hal ini Komnas HAM), pada praktiknya bisa berbeda dengan penilaian penyidik (dalam hal ini Jaksa Agung) saat menilai perkara dugaan pelanggaran hak asasi manusia.

Keadaan tersebut menimbulkan ketidakpastian yang berujung pada perlakuan diskriminasi. Komnas HAM sebagai penyelidik di satu sisi menilai berkas perkara sudah lengkap atau bukti permulaan yang cukup atas peristiwa pelanggaran hak asasi manusia, belum tentu demikian dengan penilaian dari Jaksa Agung sebagai penyidik. Penyidik sendiri di sisi lain bisa berpendapat bahwa hasil penyelidikan kurang lengkap dan mengembalikan berkas perkara ke penyelidik untuk dilengkapi dengan petunjuk.

Pertimbangan Mahkamah Konstitusi terhadap pokok permohonan Pasal 28D ayat (1) UUD NRI 1945 sangat menarik, karena tidak hanya menyajikan pertimbangan yuridis melainkan pertimbangan kontekstual dalam hal karakteristik perkara hak asasi manusia. Hakim mempertimbangkan penggunaan istilah "kurang lengkap" pada berkas penyelidikan dapat dimaklumi, mengingat perolehan bukti pada kasus pelanggaran hak asasi manusia tidak mudah diperoleh. Hakim menilai bahwa pencantuman istilah "tidak lengkap" atas berkas penyelidikan perkara dugaan pelanggaran hak asasi manusia justru menekankan kepastian hukum. Hakim tampak menempatkan penanganan perkara dugaan hak asasi manusia tidak jauh berbeda dari penanganan perkara pidana pada umumnya. Hakim menolak pandangan pemohon yang menilai keberadaan rumusan "tidak lengkap" perkara penyelidikan berpotensi menimbulkan ketidakpastian hukum.

Dasar pertimbangan hakim justru menemukan tidak adanya pertentangan norma hukum dalam ketentuan hukum a quo, sehingga Mahkamah Konstitusi memutus perkara ini dengan putusan ditolak untuk seluruhnya. Pertimbangan hakim tersebut sangat menarik untuk dibahas lebih lanjut, tidak hanya dari hukum acara pidana, melainkan dasar konstitusional yang diterapkan oleh hakim dalam memeriksa perkara tersebut. Pemahaman hakim atas asas hukum acara pidana menunjukkan pertimbangan hakim berdasarkan teori hukum acara pidana yang berlaku telah sesuai dengan kepastian hukum ataukah sebaliknya. Begitu pula 
pertimbangan putusan hakim terhadap konstitusi sangat penting dikaji lebih mendalam, apakah telah mempertimbangkan hak asasi manusia secara berimbang atau tidak.

\section{B. Rumusan Masalah}

Permohonan pengujian Pasal 20 ayat (3) Undang-Undang Pengadilan Hak Asasi Manusia terhadap UUD NRI 1945 merupakan hal yang sangat penting bagi kepastian hukum, sekaligus penegakan hak asasi manusia Indonesia. Hal yang perlu dikaji secara mendalam dari Putusan Mahkamah Konstitusi yang menolak pengujian Pasal 20 ayat (3) Undang-Undang Pengadilan Hak Asasi Manusia yaitu:

1. Apakah pertimbangan Mahkamah Konstitusi terhadap frasa "kurang lengkap" pada ketentuan hukum Pasal 20 ayat (3) Undang-Undang Pengadilan Hak Asasi Manusia sudah sesuai dengan asas hukum acara pidana?

2. Apakah pertimbangan Mahkamah Konstitusi terhadap frasa "kurang lengkap" pada ketentuan hukum Pasal 20 ayat (3) Undang-Undang Pengadilan Hak Asasi Manusia sudah sesuai dengan Pasal 28D ayat (1) UUD NRI 1945?

\section{Tujuan dan Kegunaan}

Pembahasan tulisan terkait interpretasi "kurang lengkap" dalam Putusan Nomor 75/ PUU-XIII/2015, bertujuan untuk mempelajari kesesuaian pertimbangan Mahkamah Konstitusi terhadap pemahaman asas hukum acara pidana Indonesia, dan hak asasi manusia dalam UUD NRI 1945. Kajian terhadap pertimbangan Mahkamah Konstitusi terhadap asas hukum acara pidana dan UUD NRI 1945 menunjukkan seberapa jauh asas persamaan hukum dan kepastian hukum diterapkan, sedangkan di sisi lain kajian tersebut memiliki manfaat untuk menjelaskan konsep hak asasi manusia yang dipahami Mahkamah Konstitusi untuk dijadikan panduan.

Kegunaan dari kajian putusan ini, untuk mempertimbangkan penerapan asas hukum acara pidana dan hak konstitusional yang dimiliki oleh warga masyarakat. Pemaparan diharapkan menjadi masukan dan pembelajaran tersendiribagi hakim dalam memberikan pertimbangan putusan secara utuh tidak hanya dari sisi kemanfaatan, akan tetapi asas hukum acara pidana dan konstitusi. Pemenuhan secara berimbang dari sisi asas hukum acara pidana dan hak konstitusional menunjukkan upaya memanusiakan manusia sebagaimana diamanatkan konstitusi.

\section{Tinjauan Pustaka}

Mahkamah Konstitusi sebagaimana lembaga peradilan lainnya, merupakan pelaksana kekuasaan kehakiman untuk melaksanakan peradilan guna menegakkan hukum dan keadilan (Pasal 1 angka 1 Undang-Undang Kekuasaan Kehakiman). Berbeda dengan lembaga peradilan lainnya, Mahkamah Konstitusi memiliki kewenangan untuk memeriksa dan mengadili pada tingkat pertama dan terakhir yang putusannya bersifat final terkait empat hal, yaitu: (i) kewenangan menguji undangundang terhadap UUD NRI 1945; (ii) memutus sengketa kewenangan lembaga negara yang kewenangannya diberikan oleh UUD NRI 1945; (iii) memutus pembubaran partai politik; (iv) memutus perselisihan tentang hasil pemilihan umum. Tambahan kelima, kewenangan lain yang diberikan oleh undang-undang. Terkait dengan 
studi kasus ini, kewenangan pengujian produk hukum Undang-Undang Pengadilan Hak Asasi Manusia terhadap UUD NRI 1945 menjadi sorotan pembahasan.

Kewenangan pengujian undang-undang terhadap UUD NRI 1945 atau judicial review didasarkan pada Pasal 24C ayat (1) UUD NRI 1945, dan Pasal 10 Undang-Undang Nomor 24 Tahun 2003 tentang Mahkamah Konstitusi sebagaimana telah diubah dengan UndangUndang Nomor 8 Tahun 2011. Kewenangan ini cukup menarik karena Mahkamah Konstitusi dapat memberikan pertimbangan, penilaian, dan putusan terhadap undang-undang yang diajukan pengujian, terutama undang-undang di bidang hukum pidana. Kajian Mahkamah Konstitusi terhadap undang-undang di bidang hukum pidana setidaknya mempertimbangkan dua dasar penilaian utama, yaitu asas hukum acara pidana dan hak asasi manusia yang diatur dalam UUD NRI 1945 sebagai hak konstitusional warga negara Republik Indonesia.

Hukum acara pidana sebagaimana diatur dalam KUHAP pun memiliki beberapa asas hukum yang mendasari, walaupun tidak secara eksplisit diatur. Keberadaan asas hukum tidak selalu dirumuskan dalam sebuah frasa atau kalimat khusus, melainkan dapat berbentuk rumusan ketentuan hukum yang mencerminkan pemberlakuan sebuah asas hukum.

Lamintang menyebutkan delapan asas hukum yang dimiliki hukum acara pidana KUHAP, yaitu: asas perlakuan yang sama di depan hukum, asas larangan main hakim sendiri, asas sikap hakim yang pasif, asas keterbukaan dari suatu proses peradilan, asas kebebasan hakim dalam mengadili perkara pidana, asas oportunitas, asas legalitas, dan asas praduga tidak bersalah. Terkait dengan pemahaman "kurang lengkap," ada empat asas yang relevan, yaitu:-

1. Asas pelakuan yang sama terhadap setiap orang di depan hukum (gelijkheid voor de wet), yang berarti hukum acara pidana tidak mengenal forum privilegiatum atau perlakuan yang bersifat khusus bagi pelakupelaku tertentu dari tindak pidana;

2. Asas oportunitas (opportuniteitsbeginsel), artinya jaksa memiliki kewenangan untuk menyampingkan perkara untuk tidak diproses pengadilan demi kepentingan umum atau kepentingan hukum yang menghendaki demikian;

3. Asas legalitas (legaliteitsbeginsel), artinya semua pelaku tindak pidana diproses menurut ketentuan hukum yang berlaku;

4. Asas praduga tidak bersalah (presumption of innocence), bahwa seseorang harus tetap dianggap tidak bersalah sampai kesalahannya dinyatakan terbukti oleh sidang pengadilan melalui putusan yang telah berkekuatan hukum tetap (Lamintang, 1984: 30-31).

Sebenarnya selain kedelapan asas hukum acara pidana ini, masih banyak asas hukum acara pidana lain yang berlaku dalam KUHAP. Gunarto (2016: 1) menekankan bahwa asas hukum acara pidana sebenarnya tidak hanya secara tertulis, yaitu dalam undang-undang, melainkan asas hukum acara pidana yang tidak tertulis tersebar dalam peraturan perundang-undangan terkait hukum acara pidana, termasuk hukum pidana materiil. Taibu (2016) menegaskan bahwa hakikat dari pemberlakuan hukum acara pidana sudah seharusnya mengedepankan asas akusator, yaitu memperlakukan tersangka sebagai manusia yang memiliki harkat dan martabat manusia.

Asas hukum ini menjadi pedoman bagi pelaksanaan penegakan hukum pidana materiil sebagaimana peran dari hukum pidana formal. Sebagai sebuah pedoman, asas hukum acara 
pidana walaupun berada di balik rumusan sebuah ketentuan hukum tidak hanya menjadi pedoman bagi para pihak yang berperan aktif dalam proses penegakan hukum, melainkan bagi masyarakat (Gunarto, 2016: 3).

Pertimbangan terhadap asas hukum acara pidana juga dilengkapi dengan pertimbangan konstitusional yang menjadi tugas dan wewenang Hakim Konstitusi. Terkait dengan studi kasus ini, dapat dirujuk Pasal 28D ayat (1) UUD NRI 1945 yang mengatur hak asasi manusia atas kepastian hukum dan perlakuan yang sama di hadapan hukum. Kharlie (2013: 159) menguraikan empat macam hak yang terdapat dalam Pasal 28D UUD NRI 1945 antara lain: (i) the right to recognition, security, protection, and legal certainty of fair and equal treatment before the law; (ii) the right to work and receive benefits and fair treatment; (iii) equal opportunities in government; and (iv) the right to citizenship status.

Keempat hak asasi manusia tersebut begitu mendasar dalam kehidupan berbangsa dan bernegara karena berkaitan erat dengan kedudukan, pengaturan, dan pembatasan hak seseorang di dalam ketentuan hukum. Hak atas kepastian hukum di sini bertalian erat dengan asas legalitas yang menjadi dasar penerapan hukum pidana formal, agar setiap prosedur hukum acara pidana tertulis dengan jelas dan tegas. Kepastian hukum dalam hukum pidana formal yang dikehendaki pada dasarnya bukan hanya kejelasan terhadap bagaimana prosedur hukum yang harus dilalui saat seseorang berhadapan dengan hukum, akan tetapi kejelasan ukuran penilaian yang digunakan dan waktu yang dibutuhkan dalam proses hukum acara pidana.

Isu sentral dari permohonan uji materiil Pasal 20 ayat (3) Undang-Undang Pengadilan
Hak Asasi Manusia terkait dengan kejelasan ukuran penilaian dari berkas yang dinyatakan lengkap atau kurang lengkap baik oleh penyelidik maupun penyidik. Keberadaan ukuran tersebut menjadi ukuran objektif bagi penegak hukum dalam menilai suatu berkas penyelidikan berada dalam posisi lengkap ataukah tidak lengkap, di sisi lain, hak atas persamaan di hadapan hukum pada umumnya dipahami sebagai hak seseorang untuk diperlakukan secara sama tanpa membedakan kedudukan yang dimilikinya.

Hanya saja persamaan di hadapan hukum tidak dimaksudkan pula memberikan proses dan prosedur yang sama dengan perkara pidana pada umumnya untuk tiap kasus yang ditangani hakim. Hakim sudah selayaknya mempertimbangkan karakteristik perkara yang ditangani, baik dari sisi karakteristik dan kebutuhan khusus dalam penegakan hukum.

Pertimbangan inilah yang diharapkan Pasal 5 ayat (1) Undang-Undang Kekuasaan Kehakiman, agar hakim memiliki kebebasan dalam melakukan penilaian secara kontekstual atas perkara yang dihadapinya bukan melulu menyamakan dengan perkara lainnya. Oleh karena itu, pemahaman terhadap hukum acara pidana yang berlaku dalam penanganan dugaan pelanggaran hak asasi manusia sangat berbeda dengan penanganan perkara pidana pada umumnya. Penyamaan pertimbangan hukum acara pidana sebagaimana berlaku dalam KUHAP sama artinya dengan pelanggaran konstitusional atas hak untuk mendapatkan kepastian hukum dan persamaan di hadapan hukum.

\section{METODE PENELITIAN}

Kajian terhadap Putusan Nomor 75/PUUXIII/2015 menggunakan metode penelitian 
normatif dengan pendekatan kasus (case study). Penelitian studi kasus (case study), menggunakan bahan hukum primer berupa Putusan Mahkamah Konstitusi a quo dan Undang-Undang Pengadilan Hak Asasi Manusia sebagai sumber sekaligus acuan pemahaman penelitian.

Pemahaman terhadap bahan hukum primer dibandingkan dengan teori hukum pidana dan hak asasi manusia terkait sebagai bahan hukum sekunder. Hasil dari perbandingan akan dikaji berdasarkan rumusan masalah yang ada dan ditarik kesimpulan sebagai hasil penelitian.

\section{HASIL DAN PEMBAHASAN}

\section{A. Kajian Hukum Pertimbangan Mahkamah Konstitusi berdasarkan Asas-Asas Hukum Acara Pidana}

Peran penting asas hukum acara pidana dalam pertimbangan hakim pada Putusan Nomor 75/PUU-XIII/2015, dapat dilihat pada asas hukum acara pidana yang dipertimbangkan oleh Mahkamah Konstitusi. Kajian terhadap pertimbangan Mahkamah Konstitusi atas asas hukum acara pidana terhadap permohonan judicial review Pasal 20 ayat (3) Undang-Undang Pengadilan Hak Asasi Manusia sepanjang frasa "kurang lengkap" dapat ditinjau dari beberapa hal yaitu:

1. Penekanan Sistem Peradilan Ditekankan sebagai Due Process of Law.

Due process of law yang berarti sistem peradilan dilakukan berdasarkan tugas dan kewenangan yang jelas dari tiap lembaga demi tujuan penegakan hukum. Menurut Mahkamah Konstitusi, pembentukan Pengadilan Hak Asasi Manusia ditujukan untuk penyelesaian pelanggaran hak asasi manusia yang berat (Pasal
104 ayat (1) Undang-Undang Nomor 39 Tahun 1999) dengan dua pertimbangan utama yaitu: (i) pelanggaran hak asasi manusia merupakan extra ordinary crime; dan (ii) penting adanya langkah penyelidikan, penyidikan, penuntutan, dan pemeriksaan yang bersifat khusus terkait pihak yang terlibat, prosedur, dan waktu pelaksanaan (MK RI, 2016: 80).

Pertimbangan Mahkamah Konstitusi dalam pokok permohonan pertama ini menunjukkan pemberlakuan asas persamaan di hadapan hukum dan penafsiran historis yuridis dalam memahami keberadaan Komnas HAM dan Kejaksaan Agung. Mahkamah Konstitusi tidak serta merta mengambil alih pandangan dari pemohon, keterangan presiden maupun keterangan Kejaksaan Agung.

Mahkamah Konstitusi lebih menekankan pemahaman historis dari arti penting dan tujuan pembentukan Pengadilan Hak Asasi Manusia yang terkait erat dengan Komnas HAM dan Kejaksaan Agung. Sikap Mahkamah Konstitusi ini menunjukkan penerapan asas kebebasan hakim dalam mengadili. Mahkamah Konstitusi tidak mau terikat pada satu pandangan tertentu, namun lebih menggali pentingnya pengaturan khusus dalam penegakan hak asasi manusia yang berat.

Pertimbangan ditekankan pada konsiderans menimbang huruf $\mathrm{b}$ dan Penjelasan Umum Undang-Undang Pengadilan Hak Asasi Manusia dengan demikian menekankan landasan filosofis daripada yuridis semata. Pertimbangan Mahkamah Konstitusi ini sangat penting dalam pemeriksaan pengadilan yang dicatat dalam pertimbangan putusan hakim, karena dari pertimbangan inilah tampak kedudukan hakim yang bebas dan tidak memihak pihak manapun. 
2. Penggunaan Frasa "Kurang Lengkap."

Ketentuan hukum Pasal 20 ayat (3) dan penjelasannya tidak memberikan penjelasan terkait ukuran objektif dari lengkapnya berkas perkara penyelidikan. Pasal 8 dan Pasal 9 Undang-Undang Pengadilan Hak Asasi Manusia merupakan ukuran pelanggaran hak asasi manusia berat, sehingga berkaitan erat dengan substansi perbuatan yang dilakukan oleh tersangka. Ukuran berkas penyelidikan dapat dikatakan lengkap atau tidak lengkap merupakan permasalahan teknis administratif dalam penegakan hukum yang ternyata menimbulkan persoalan dari sisi kepastian hukum.

Mahkamah Konstitusi sendiriberpandangan bahwa frasa "bukti permulaan yang cukup" yang dimaksud dalam Pasal 20 ayat (1) UndangUndang Pengadilan Hak Asasi Manusia adalah bukti yang cukup untuk menduga: (a) telah terjadi pelanggaran hak asasi manusia yang berat berupa kejahatan genosida yang dilakukan dengan cara tertentu (Pasal 8 Undang-Undang Nomor 26 Tahun 2000); dan (b) telah terjadi pelanggaran hak asasi manusia yang berat berupa kejahatan kemanusiaan yaitu dalam "rupa" sebagaimana dimaksud Pasal 9 Undang-Undang Nomor 26 Tahun 2000.

Tegasnya, "kurang lengkap" dimaksud bisa berkenaan dengan ketidakjelasan genosida atau kejahatan terhadap kemanusiaan, atau berkenaan dengan "cara" tindak pidana itu dilakukan (dalam hal kejahatan genosida), atau berkenaan dengan "rupa" kejahatan itu (dalam hal kejahatan terhadap kemanusiaan), atau berkenaan dengan bukti-bukti mengenai tindak pidana itu (baik untuk kejahatan genosida atau kejahatan terhadap kemanusiaan), karena itu ditegaskan Pasal 20 ayat (3) Undang-Undang Pengadilan Hak Asasi
Manusia atau kombinasi dari kemungkinankemungkinan tersebut (MK RI, 2016: 82).

Pokok permohonan kedua ini dapat dikatakan menjadi kunci dari permohonan uji konstitusional Pasal 20 ayat (3) dan penjelasannya Undang-Undang Pengadilan Hak Asasi Manusia. Pokok permasalahan terdapat dalam hal perbedaan penilaian dari penyelidik (Komnas HAM) dan penyidik (Kejaksaan Agung) bersumber pada frasa "kurang lengkap" dari ketentuan hukum a quo. Mahkamah Konstitusi dalam pertimbangannya terlihat menggunakan penafsiran sistematis dengan mengaitkan pemahaman frasa "kurang lengkap" (Pasal 20 ayat (3) dan penjelasannya) dengan Pasal 8 dan Pasal 9 Undang-Undang Pengadilan Hak Asasi Manusia.

Frasa "kurang lengkap" dalam Pasal 20 ayat (3) dan penjelasannya tidak dapat serta merta dipahami dari satu sisi pemahaman lembaga penegak hukum, melainkan harus dilakukan dengan hati-hati. Proses hukum pada dasarnya mengurangi hak asasi manusia yang dimiliki oleh seseorang yang diduga melakukan perbuatan yang dilarang. Oleh karena itu koordinasi dan sikap cermat harus dimiliki oleh penyelidik maupun penyidik. Uniknya, Mahkamah Konstitusi dalam memaparkan penjelasannya memaparkan maksud dan ruang lingkup dari frasa "kurang lengkap" yang dimaksudkan terkait dengan bukti tindak pidana, cara tindak pidana dilakukan (bila kejahatannya genosida), atau "rupa" (bila kejahatannya kejahatan kemanusiaan), atau mungkin kombinasi di antara keduanya.

Mahkamah Konstitusi justru memberikan pertimbangan berbeda dalam menanggapi persoalan ini dengan mendasarkan pada pemahaman sistematis (Said, 2012: 187-375), yaitu pemahaman secara keseluruhan dari 
undang-undang terhadap hubungan kewenangan penyelidik (c.q. Komnas HAM) dengan penyidik (c.q. Jaksa Agung) dalam penanganan perkara hak asasi manusia berat, yaitu:

a. Kedudukan dan kewenangan penyelidik (Komnas HAM) dan penyidik (Jaksa Agung);

b. Pengertian ruang lingkup penyelidikan pelanggaran hak asasi manusia berat;

c. Komnas HAM bila mendapatkan bukti yang cukup adanya peristiwa pelanggaran hak asasi manusia berat disampaikan kepada penyidik;

d. Komnas HAM wajib menjelaskan cara dan bagaimana kejahatan itu dilakukan dalam kejahatan genosida atau dalam rupa apa kejahatan kemanusiaan itu dilakukan;

e. Dua syarat bukti permulaan yang cukup yaitu telah terjadi pelanggaran hak asasi manusia berat berupa genosida atau telah terjadi pelanggaran hak asasi manusia berat berupa kejahatan terhadap kemanusiaan;

f. Uraian lengkap bukti permulaan itu diserahkan kepada penyidik;

g. Penyidik menilai hasil penyelidikan;

h. Bila penyidik menyatakan belum lengkap, maka berkas dikembalikan kepada penyelidik disertai petunjuk untuk dilengkapi dalam waktu 30 hari;

i. "Kurang lengkap" dipahami dalam hubungannya dengan ketidakjelasan tentang tindak pidananya sendiri (genosida atau kejahatan terhadap kemanusiaan), atau cara tindak pidana itu dilakukan atau bukti-bukti mengenai tindak pidana itu (MK RI, 2016: 81-82).

Kesembilan poin tersebut merupakan tahapan dalam beralihnya berkas perkara dari penyelidik kepada penyidik, atau dengan kata lain tahap dan kelengkapan "serah terima" berkas perkara dari penyelidik dan penyidik. Pemahaman frasa "kurang lengkap" pada dasarnya dipahami dalam penilaian berkas perkara oleh penyidik yang dalam hal ini diberikan kewenangan untuk melakukan penyidikan dan penuntutan atas perkara pelanggaran hak asasi manusia berat.

Kekuasaan untuk menilai berkas perkara sudah lengkap atau kurang lengkap berada pada Jaksa Agung, sehingga penyelidik harus taat pada penilaian tersebut. Sekilas posisi tersebut memang tampak tidak seimbang antara penyelidik dan penyidik, hanya jika mencermati pengaturan Undang-Undang Pengadilan Hak Asasi Manusia memang demikian adanya. Mahkamah Konstitusi sudah tepat dalam menggunakan penafsiran sistematis terhadap pemaknaan Pasal 20 ayat (3) Undang-Undang Pengadilan Hak Asasi Manusia.

Pertimbangan tersebutmenunjukkankehatihatian dalam menempatkan kepentingan yang dimiliki oleh tiap pihak. Mahkamah Konstitusi dalam pertimbangan pokok permohonan kedua tidak terjebak pada perdebatan ukuran dan kerugian yang timbul. Mahkamah Konstitusi justru menjelaskan secara sistematis apa yang dimaksud dengan frasa "kurang lengkap" dalam ketentuan hukum a quo. Sikap Mahkamah Konstitusi tersebut jelas menunjukkan penerapan asas persamaan di hadapan hukum sebagaimana diemban dalam Pasal 28H UUD NRI 1945. Persamaan di sini dimaknai oleh Mahkamah Konstitusi tidak terbatas pada kedudukan formal di hadapan hukum, melainkan kepentingan yang sama dipertimbangkan untuk memperoleh kepastian hukum. Uraian penjelasan Mahkamah Konstitusi menunjukkan penghargaan bagi semua pihak yang berbeda pendapat akan ukuran frasa "kurang lengkap" dalam pasal a quo. 
3. Kelanjutan Proses Penyidikan Dugaan

Perkara Pelanggaran Hak Asasi Manusia Berat.

Pembagian tugas penyelidikan oleh Komnas HAM dan penyidikan oleh Jaksa Agung menunjukkan perhatian khusus terhadap penanganan perkara pelanggaran hak asasi manusia yang berat agar mengedepankan profesionalitas dan ketidakberpihakan (netral). Jaksa Agung memang memiliki wewenang untuk melakukan penyidikan terhadap perkara pelanggaran hak asasi manusia berat, hanya saja dalam pelaksanaannya membutuhkan kejelasan ukuran objektif dapat atau tidaknya berkas perkara dapat ditingkatkan pada tahap penyidikan. Mahkamah Konstitusi sendiri memiliki pandangan bahwa Undang-Undang Pengadilan Hak Asasi Manusia tidak memberikan pengaturan khusus tentang penyelidikan maupun penyidikan, sehingga hukum acaranya diberlakukan KUHAP.

Kewenangan untuk menentukan dapat atau tidaknya dilakukan penyidikan terhadap hasil penyelidikan Komnas HAM tentang dugaan adanya pelanggaran hak asasi manusia yang berat adalah penyidik, dalam hal ini Jaksa Agung (Pasal 20 Undang-Undang Pengadilan Hak Asasi Manusia). Mahkamah Konstitusi menekankan "bahwa apabila berdasarkan penyelidikan Komnas HAM berpendapat telah terdapat bukti permulaan yang cukup terjadi peristiwa pelanggaran hak asasi manusia yang berat, maka penyelidikan disampaikan kepada penyidik" (MK RI, 2016: 83). Artinya, Mahkamah Konstitusi sama sekali tidak mempertimbangkan kekhususan yang terdapat dalam proses hukum acara pidana perkara hak asasi manusia berat. Mahkamah Konstitusi menyamakan penanganan perkara hak asasi manusia berat dengan penanganan perkara pidana pada umumnya.
Berdasarkan pertimbangan tersebut, Mahkamah Konstitusi telah mengesampingkan beberapa asas hukum acara pidana, antara lain asas legalitas, asas persamaan di hadapan hukum, dan asas kebebasan hakim. Undang-Undang Pengadilan Hak Asasi Manusia menghendaki suatu prosedur hukum acara pidana khusus bukan prosedur hukum acara pidana sebagaimana berlaku dalam KUHAP.

Pertimbangan Mahkamah Konstitusi atas ketiadaan penjelasan frasa "kurang lengkap" kepada KUHAP justru tidak bertentangan dengan asas legalitas yang menghendaki penanganan khusus atas perkara pelanggaran hak asasi manusia berat. Langkah Mahkamah Konstitusi memang dapat dipahami berdasarkan prinsip lex generalis sebagai dasar rujukan pemahaman undang-undang khusus sepanjang tidak memberikan pengaturan. Hanya saja penanganan perkara pelanggaran hak asasi manusia berat sudah seharusnya mendapatkan pertimbangan dari sisi karakteristik perkara yang ditangani dan tantangan yang harus dihadapi oleh penegak hukum.

Mahkamah Konstitusi juga dipandang tidak mengindahkan asas persamaan di hadapan hukum dalam mempertimbangkan judicial review ini. Persamaan di hadapan hukum dalam perkara ini tidak boleh dibatasi pada kesamaan hak yang diperoleh seseorang pada saat berhadapan dengan hukum atau proses hukum. Persamaan di sini juga harus mempertimbangkan kontekstualitas perkara hak asasi manusia berat yang sangat berbeda dengan perkara pidana pada umumnya. Sebuah ilustrasi, A seorang anggota militer sudah seharusnya diadili menurut hukum acara pengadilan militer dengan mempertimbangkan karakteristik khusus bidang militer. Begitu pula halnya pemberlakuan KUHAP dalam memahami keberlanjutan penyidikan perkara hak asasi 
manusia berat justru mengesampingkan asas persamaan di hadapan hukum.

Terakhir, Mahkamah Konstitusi juga tidak menggunakan asas kebebasan hakim dalam menggali nilai hukum yang terkandung dalam Undang-Undang Pengadilan Hak Asasi Manusia. Pertimbangan Mahkamah Konstitusi lebih mengedepankan pemahaman historis yuridis dari pembentukan Undang-Undang Pengadilan Hak Asasi Manusia, namun tidak dijadikan dasar pertimbangan putusan. Hal tersebut tampak pada saat Mahkamah Konstitusi serta merta merujuk KUHAP dalam memahami tindak lanjut penyidikan.

\section{Mahkamah Konstitusi telah} mengesampingkan nilai hukum yang terkandung dalam Undang-Undang Pengadilan Hak Asasi Manusia yang menghendaki kepastian hukum dan keterbukaan dalam proses penegakan hukum. Mengingat perkara hak asasi manusia berat merupakan perkara yang memiliki dimensi politis dan keamanan yang tinggi dan sangat sensitif, sudah seharusnya Mahkamah Konstitusi mengedepankan pentingnya kejelasan atas prosedur dan ukuran yang digunakan dalam penilaian berkas perkara. Tidak dapat dipungkiri bahwa Jaksa Agung memiliki kewenangan yang kuat untuk menuntut atau tidak menuntut perkara pidana demi ketertiban umum berdasarkan asas oportunitas. Hanya saja asas ini dapat diberlakukan jika posisi perkara yang dihadapi sudah jelas memiliki bukti sebagai perkara pidana. Penggunaan asas oportunitas tidak dapat digunakan untuk mengesampingkan penilaian berkas perkara penyelidikan sebagaimana diajukan oleh Komnas HAM.

Perbandingan dari ketiga pandangan tersebut cukup memberikan pemahaman yang unik. Pemohon dalam pokok permohonan ketiga justru menekankan bahwa tugas untuk melengkapi berkas perkara dugaan pelanggaran hak asasi manusia berat merupakan tugas penyidik (Kejaksaan Agung). Kejaksaan Agung justru menekankan bahwa keberadaan frasa "kurang lengkap" justru melindungi persamaan dan keadilan baik bagi pelaku maupun korban dan keluarganya. Hal ini cukup sulit bagi penegak hukum yang memiliki tugas mencari bukti untuk menunjukkan kesalahan tersangka. Belum lagi kesadaran penegak hukum atas asas praduga tidak bersalah menjadi kendala lain (Tryan P, Puterajaya, \& Pujiyono, 2016: 4) yang mempersulit pemenuhan asas ini pada saat bolakbalik berkas perkara.

Tersangka seringkali berada pada posisi yang dirugikan atas kondisi bolak-balik perkara karena dengan demikian ia seolah "diupayakan" bersalah di hadapan hukum. Jaksa penuntut umum lebih mengambil posisi hati-hati dalam melakukan penegakan hukum atas perkara hak asasi manusia berat karena tidak ingin bertindak gegabah yang berujung pada pengurangan hak asasi manusia dengan mengatasnamakan hukum. Di sisi lain, kondisi ini merugikan masyarakat pencari keadilan atas pelanggaran hak asasi manusia berat. Lebih unik lagi, Mahkamah Konstitusi justru memberikan penilaian terhadap regulasi Undang-Undang Pengadilan Hak Asasi Manusia yang tidak memberikan kejelasan tentang penyelidikan dan penyidikan.

Ketidakjelasan pengertian ini patut disayangkan mengingat Undang-Undang Pengadilan Hak Asasi Manusia memiliki sifat khusus yang tidak semestinya merujuk pada KUHAP. Mahkamah Konstitusi dalam posisi ini mencoba memahami kesulitan yang dihadapi oleh Komnas HAM sebagai akibat ketidakjelasan 
pengaturan prosedur dari penegakan hukum khusus atas perkara dugaan pelanggaran hak asasi manusia berat dengan merujuk KUHAP. Pertimbangan Mahkamah Konstitusi justru mengesampingkan kekhususan karakteristik perkara pelanggaran hak asasi manusia berat yang membutuhkan kejelasan dari sisi prosedur maupun ukuran penilaian berkas perkara penyelidikan dinyatakan lengkap.

\section{Bolak-Balik Berkas Perkara Bukan Sebagai Kewenangan Mahkamah Konstitusi.}

Pemberlakuan Pasal 20 ayat (3) UndangUndang Pengadilan Hak Asasi Manusia terkait dengan frasa "kurang lengkap" memang memberikan peluang terjadinya bolak-balik perkara sebagaimana dimungkinkan dalam KUHAP. Kondisi tersebut sebenarnya sudah diantisipasi oleh Undang-Undang Pengadilan Hak Asasi Manusia dengan mengharuskan penyidik memberikan supervisi kepada penyelidik. Hanya saja pada praktiknya kondisi bolak-balik berkas perkara tetap terjadi sebagai akibat perbedaan pemahaman ukuran penilaian berkas perkara yang dianggap lengkap. Tentu saja hal ini merupakan akibat langsung dari rumusan "tidak lengkap" dalam Pasal 20 ayat (3) Undang-Undang Pengadilan Hak Asasi Manusia yang penilaiannya diberikan kepada penyidik. Mahkamah Konstitusi menilai bahwa tidak terdapat pertentangan norma Pasal 20 ayat (3) dan penjelasannya terhadap UUD NRI 1945.

Perbedaan yang terjadi antara penyidik dan penyelidik tentang pengertian "kurang lengkap" dan "petunjuk" merupakan masalah penerapan norma, khususnya berkaitan dengan substansi formal dan materiil tentang penyelidikan dan penyidikan sehingga berada di luar kewenangan
Mahkamah Konstitusi menilainya. Perihal tidak adanya ketentuan hukum yang mengatur saat terjadi perbedaan pendapat antara penyidik dan penyelidik serta tidak adanya ketentuan yang mengatur jika dalam 30 hari tidak mampu melengkapi kekurangan hasil penyelidikan maka kedua hal ini bukan kewenangan Mahkamah Konstitusi (MK RI, 2016: 83-84).

Pandangan Mahkamah Konstitusi terhadap pokok permohonan keempat lebih menekankan penilaian ada atau tidaknya pertentangan norma dari permohonan yang diajukan. Pokok persoalan yang dipahami oleh Mahkamah Konstitusi lebih terkait dengan penerapan norma hukum Pasal 20 ayat (3) Undang-Undang Pengadilan Hak Asasi Manusia. Hal tersebut justru menunjukkan Mahkamah Konstitusi mengesampingkan adanya akibat langsung dari frasa "kurang lengkap" dan penilaian berkas perkara penyelidikan dari penyelidik. Tentu saja hal ini membawa dampak serius bagi asas kepastian hukum dan keterbukaan yang disyaratkan dalam hukum acara pidana.

Keterbukaan dari suatu proses peradilan menjadi jaminan penting bukan hanya bagi tersangka, namun masyarakat pencari keadilan. Tiap tahap proses hukum acara pidana menghadirkan hak dan kewajiban yang berbeda bagi tersangka untuk mempertahankan hak asasi manusia yang dimilikinya termasuk dalam hal ini bantuan hukum. Berkas perkara yang harus mengalami bolak-balik justru merugikan hak seseorang yang menjadi tersangka. Hal tersebut sesuai dengan peran yang seharusnya dimiliki oleh tersangka dalam proses hukum acara pidana secara langsung (Claudia, 2015: 117-119), sehingga kepentingannya dapat dilindungi.

Terkait pandangan ini, Mahkamah Konstitusi memang menunjukkan sikap 
ketidakberpihakannya atas perkara yang diajukan. Mahkamah Konstitusi menekankan bahwa kondisi bolak-balik perkara merupakan keniscayaan yang dapat diantisipasi dengan memberikan petunjuk kepada penyelidik terkait substansi formal atau materiil yang harus dilengkapi.

Berdasarkan pandangan tersebut, Mahkamah Konstitusi tidak memberikan solusi baru bagi kemacetan proses penegakan hukum perkara dugaan pelanggaran hak asasi manusia berat. Kondisi tersebut justru menimbulkan ketidakpastian hukum tidak hanya bagi masyarakat atau keluarga korban hak asasi manusia berat, akan tetapi tersangka.

\section{B. Kajian Pertimbangan Mahkamah Konstitusi Berdasarkan Hak Asasi Manusia dalam Pasal 28D UUD NRI 1945}

Kajian terhadap pertimbangan Mahkamah Konstitusi atas permohonan uji materiil frasa "kurang lengkap" Pasal 20 ayat (3) UndangUndang Pengadilan Hak Asasi Manusia terhadap UUD NRI 1945 akan lebih difokuskan pada Pasal 28D UUD NRI 1945. Hak konstitusional yang bersinggungan secara langsung terhadap pengujian undang-undang terletak pada the right to recognition, security, protection, and legal certainty of fair and equal treatment before the law. Dua hak utama yang akan disinggung dalam pembahasan terkait dengan hak atas kepastian hukum dan persamaan kedudukan di hadapan hukum.

Keberadaan frasa "kurang lengkap" bagi pemohon dinilai memberikan dampak diskriminasi bagi pencari keadilan, terutama korban pelanggaran hak asasi manusia berat untuk mendapatkan kompensasi, restitusi, dan rehabilitasi. Mahkamah Konstitusi menilai tidak terdapat persoalan diskriminasi baik dalam rumusan norma Pasal 20 ayat (3) maupun penjelasan Undang-Undang Pengadilan Hak Asasi Manusia. Mengingat pemahaman “diskriminasi” menurut Pasal 1 angka 3 UndangUndang Pengadilan Hak Asasi Manusia dan Pasal 2 ayat (1) International Covenant on Civil and Political Rights.

Mahkamah Konstitusi mencoba memahami ruang lingkup diskriminasi sebagaimana dimaksudkan pemohon menurut ketentuan hukum Pasal 1 angka 3 Undang-Undang Pengadilan Hak Asasi Manusia dan Pasal 2 ayat (1) International Covenant on Civil and Political Rights. Mahkamah Konstitusi menilai bahwa pengertian diskriminasi dalam Undang-Undang Pengadilan Hak Asasi Manusia dan International Covenant on Civil and Political Rights tidak dapat ditemukan dalam kondisi kerugian yang dialami pemohon. Posisi pemahaman Mahkamah Konstitusi ini menunjukkan penafsiran kontekstual dengan merujuk pada undang-undang terkait. Mahkamah Konstitusi pun dalam hal ini dapat dinilai telah mengutamakan persamaan hukum atas pihak yang bersengketa dengan mendasarkan diri pada ketentuan hukum yang berlaku.

Hal yang menarik dalam pertimbangan putusan Mahkamah Konstitusi terhadap persoalan ini tampak pada titik pertimbangan yang tidak hanya mempertimbangkan rumusan ketentuan hukum secara letterlijk, tetapi juga kepentingan penegakan hak asasi manusia. Pertimbangan Mahkamah Konstitusi ternyata memiliki sifat legal justice, moral justice, dan social justice (Sudaryanto, 2012: 56), atau dalam pemahaman serupa Maggalatung (2014: 188) menyebutkan sifat legal justice sebagai asas 
keadilan hukum yang mengharuskan putusan hakim berdasarkan norma dan kaidah hukum, asas keadilan sosial (social justice) sebagai fakta hukum di masyarakat, serta asas keadilan moral (moral justice).

Sifat legal justice tampak dengan jelas pada pertimbangan Mahkamah Konstitusi yang selalu memahami ketentuan hukum (c.q. penyelidikan dan penuntutan) sebagai kewenangan dan tata prosedur yang telah diatur secara khusus dalam Undang-Undang Pengadilan Hak Asasi Manusia maupun KUHAP. Pertimbangan Mahkamah secara yuridis normatif pun berdasar pada kewenangan yang dimiliki oleh Komnas HAM dan Jaksa Agung yang dirangkai dengan pemahaman tahapan penyelidikan dan penuntutan (pertimbangan Mahkamah Konstitusi paragraf 3.12).

Pertimbangan Mahkamah Konstitusi di satu sisi juga melibatkan kepentingan masyarakat secara lebih luas (social justice) dengan menegaskan pentingnya upaya penegakan hak asasi manusia berat sebagai perkara pidana dengan karakteristik khusus, sehingga membutuhkan penanganan yang khusus pula sebagaimana tertulis dalam paragraf 3.10 pertimbangan Putusan Mahkamah Konstitusi.

Hal terakhir yang tidak kalah pentingnya, Mahkamah Konstitusi tidak tinggal diam ketika melihat terdapat permasalahan yang merugikan pihak masyarakat yang dalam hal ini keluarga dari korban pelanggaran hak asasi manusia berat. Pertimbangan Mahkamah Konstitusi terkait uji konstitusional Pasal 20 ayat (3) Undang-Undang Pengadilan Hak Asasi Manusia tidak berhenti dengan menyatakan bahwa permohonan tidak beralasan menurut hukum.

Mahkamah Konstitusi justru memberikan tiga solusi untuk dijadikan catatan bagi pembentuk undang-undang supaya dapat memberikan perbaikan lebih lanjut. Pertimbangan ini sebenarnya berada di luar kewenangan Mahkamah Konstitusi, hanya pertimbangan ini justru menunjukkan perhatian Mahkamah Konstitusi akan adanya risiko kerugian yang dapat dialami oleh warga negara terkait dugaan pelanggaran hak asasi manusia berat.

Pandangan Mahkamah Konstitusi ini bersifat partikular terhadap hak asasi manusia. Hak asasi manusia terkait kepastian hukum menjadi hal yang tergantung pada prosedur (Marzuki, 2013: 191) yang sudah ditetapkan oleh pembentuk undang-undang secara kontekstual. Pertimbangan tersebut jelas tidak memberikan jawaban bagi permasalahan jaminan kepastian hukum akibat bolak-balik berkas perkara pidana yang terjadi baik pada dugaan pelanggaran hak asasi manusia berat dan perkara pidana umum.

Secara moral justice, Mahkamah Konstitusi mencatat bahwa kondisi bolakbalik berkas perkara pidana harus dijadikan pertimbangan bagi pembentuk undangundang untuk memperbaiki dalam tiga catatan penting, yaitu: (1) pentingnya solusi saat terjadi perbedaan pendapat antara penyelidik dan penyidik; (2) solusi manakala penyelidik tidak mampu menyelesaikan penyempurnaan berkas perkara yang dikembalikan dalam 30 hari; serta (3) langkah hukum yang dapat ditempuh oleh warga negara sebagai pihak yang dirugikan apabila terjadi kondisi (1) dan (2) (pertimbangan Mahkamah Konstitusi paragraf 3.17).

Berdasarkan dari ketiga ukuran ini maka putusan Mahkamah Konstitusi dapat dinilai sebagai putusan yang berkualitas karena dapat dipertanggungjawabkan dari sisi kepastian hukum dan kemanfaatan, melainkan juga mencerminkan 
keadilan dan nilai kemanusiaan (Sutatiek, 2013: 4). Kepastian hukum identik dengan sifat legal justice, kemanfaatan dilihat sebagai sifat social justice, sedangkan muatan nilai keadilan dan kemanusiaan terangkum dalam sifat putusan yang moral justice.

Suasana keadilan hukum pun tidak terbatas pada keadilan prosedural yang hanya memenuhi ketentuan hukum melainkan keadilan substantif yang diharapkan masyarakat. Mahkamah Konstitusi telah dapat "menyelami suara hati masyarakat" (Syamsudin, 2014: 22) sehingga kepentingan yang dipertimbangkan bukan hanya kepentingan pemohon, tetapi kepentingan masyarakat di masa kini dan mendatang. Di sinilah peran strategis putusan Mahkamah Konstitusi.

\section{KESIMPULAN}

Putusan Mahkamah Konstitusi atas pengujian Pasal 20 ayat (3) dan penjelasannya Undang-Undang Nomor 26 Tahun 2000 memiliki dua aspek penting dalam bidang hukum acara pidana yaitu:

1. Pertimbangan Mahkamah Konstitusi terhadap pengujian Pasal 20 ayat (3) dan penjelasannya Undang-Undang Nomor 26 Tahun 2000 terhadap Pasal 28D UUD NRI 1945 telah menunjukkan pemberlakuan asas persamaan di hadapan hukum yang diberlakukan dalam hukum acara pidana terbatas pada hak tersangka. Mahkamah Konstitusi lebih menonjolkan penafsiran sistematis historis dalam memahami proses penegakan hukum acara pidana atas perkara hak asasi manusia berat, sehingga tidak mempertimbangkan karakteristik penegakan hukum atas perkara hak asasi manusia berat yang membutuhkan kekhususan. Pasal 20 ayat (3) dan penjelasannya berharap menghadirkan suasana koordinatif bagi penyelidik dan penyidik, namun tidak memberikan dasar ukuran penilaian yang jelas dan objektif atas berkas perkara dinyatakan lengkap. Perbedaan penilaian terhadap frasa "kurang lengkap" akan menjadi masalah dalam penerapan hukum yang seharusnya diantisipasi dengan pemberian petunjuk kepada penyelidik secara tuntas, bukan bolak-balik.

2. Pertimbangan Mahkamah Konstitusi juga dinilai telah mempertimbangkan Pasal 28D UUD NRI 1945 dengan menonjolkan sifat legal justice melalui pertimbangan ciri khusus penanganan perkara hak asasi manusia menurut Undang-Undang Pengadilan Hak Asasi Manusia terkait KUHAP yang menerapkan asas keadilan sosial (social justice). Mahkamah Konstitusi menyadari kondisi bolak-balik terjadi akibat tidak adanya parameter yang jelas tentang frasa "kurang lengkap" sebagai permasalahan praktik hukum, bukan permasalahan konstitusional, serta asas keadilan moral (moral justice) ketika Mahkamah Konstitusi menyadari bahwa kondisi bolak-balik perkara akibat tidak jelasnya frase "kurang lengkap" perlu diselesaikan dengan mencari: (i) solusi bila terjadi perbedaan pendapat antara penyelidik dan penyidik; (ii) solusi manakala penyelidik tidak mampu menyelesaikan penyempurnaan berkas perkara yang dikembalikan dalam 30 hari; serta (iii) langkah hukum yang dapat ditempuh oleh warga negara sebagai pihak yang dirugikan apabila terjadi kondisi (i) dan (ii). 


\section{DAFTAR ACUAN}

Claudia, N. (2015, Juni). Pendekatan keadilan restoratif: Upaya melibatkan partisipasi korban \& pelaku secara langsung dalam penyelesaian perkara pidana. Jurnal Veritas et Justitia, 1(1), 111-135.

Gunarto, M.P. (2016, Mei). “Asas-asas Hukum Acara Pidana." Makalah Simposium \& Penataran Nasional \& Pelatihan Hukum Pidana \& Kriminologi III. Banjarmasin: Universitas Lambung Mangkurat.

Kharlie, A.T. (2013, Juni). Human Rights in Indonesian Constitution Amendment. Jurnal Cita Hukum, 1 (1), 151-162.

Lamintang, P.A.F. (1984). Kitab Undang-Undang Hukum Acara Pidana dengan pembahasan secara yuridis menurut yurisprudensi \& ilmu pengetahuan hukum pidana. Bandung: Sinar Baru.

Maggalatung, A.S. (2014, Desember). Hubungan antara fakta, norma, moral \& doktrin hukum dalam pertimbangan putusan hakim. Jurnal Cita Hukum, I1 (2), 185-192.

Marzuki, S. (2013, Desember). Perspektif Mahkamah Konstitusi tentang hak asasi manusia (Kajian tiga putusan Mahkamah Konstitusi Nomor 065/ PUU-II/2004; Nomor 102/PUU-VII/2009 \& Nomor 140/PUU-VII/2009). Jurnal Yudisial, 6(3), 189-206.

Said, I.M. (2012, Juni). Kajian semantik terhadap produk hukum tertulis di Indonesia. Jurnal Mimbar Hukum, 24(2), 187-375.

Sudaryanto, A. (2012, November). Tugas \& peran hakim dalam melakukan penemuan hukum/ rechtvinging (i.c. Penafsiran Konstitusi sebagai metode penemuan hukum). Jurnal Konstitusi, 4(1), 7-42.
Sutatiek, S. (2013, Agustus). Akuntabilitas moral hakim dalam memeriksa, mengadili, \& memutus perkara agar putusannya berkualitas. Jurnal Arena Hukum, 6(1), 1-21.

Syamsudin, M. (2014, April). Keadilan prosedural \& substantif dalam putusan sengketa tanah Magersari (Kajian Putusan Nomor 74/ PDT.G/2009/PN.YK). Jurnal Yudisial, 7(1), 18-33.

Taibu, R. (2016, tanpa bulan). Ketidakpastian hukum jangka waktu penetapan status tersangka dari proses penyidikan sampai pelimpahan perkara ke persidangan. Jurnal Prioris, 5(2), 187-198.

Tryan P, M.S., Puterajaya, N.S., \& Pujiyono. (2016). Tinjauan yuridis terhadap pelaksanaan asas praduga tak bersalah dalam proses peradilan pidana. Diponegoro Law Journal, 5(4), 1-13, 